\title{
Settler Anxiety and State Support for Missionary Schooling in Colonial British Columbia, 1849-1871
}

\section{Sean Carleton}

Mount Royal University

\begin{abstract}
Indigenous peoples and settlers engaged in innumerable conflicts in the colonies of Vancouver Island and British Columbia between 1849 and 1871. The constant threat of violent Indigenous resistance to settler colonization in the Pacific Northwest - both real and imagined-produced feelings of anxiety for settlers, especially state officials, that shaped colonial strategy and statecraft. To buttress colonial security, the nascent state partnered with Christian missionaries in the hope that missionaries could use education to cultivate the goodwill of Indigenous peoples and train them to accept colonization. The state's support for early missionary schooling in colonial British Columbia is examined in the context of settler anxieties regarding three instances of Indigenous resistance: a Lekwungen convergence at Fort Victoria in 1851, the Puget Sound War of 1855-56, and the 1864 Tsilhqot'in War. In different ways, settler anxiety over these conflicts acted as a catalyst, prodding the state to support missionary schooling as a financially expeditious way of trying to contain Indigenous resistance and safeguard colonial security.
\end{abstract}

\section{RÉSUMÉ}

Entre 1849 et 1871, les colonies de l'île de Vancouver et de la Colombie-Britannique sont le lieu d'innombrables conflits entre les peuples autochtones et les colons. La menace constante — réelle et imaginaire — d'une résistance violente des Autochtones à la colonisation dans le nord-ouest du Pacifique a engendré un sentiment d'anxiété chez les colons, et en particulier chez les fonctionnaires de l'État, ce qui a façonné la stratégie et la gestion coloniale. Afin de renforcer la sécurité coloniale, l'État naissant s'est associé avec les missionnaires chrétiens dans l'espoir qu'ils utilisent l'éducation afin d'assurer la bienveillance des peuples autochtones et de les amener à accepter la colonisation. Cet article examine le soutien apporté par l'État aux premiers efforts d'enseignement missionnaire en Colombie-Britannique coloniale, dans le contexte des inquiétudes des colons par rapport à trois actes de résistance autochtone : un rassemblement Lekwungen au Fort Victoria en 1851, la guerre du Puget Sound de 1855-1856 et la guerre des Tsilhqot'in de 1864. À maints égards, l'inquiétude des colons alimentée par ces conflits a agi comme un catalyseur, poussant l'État à soutenir l'enseignement missionnaire dans l'espoir d'arriver à contenir la résistance autochtone et à assurer la sécurité coloniale à peu de frais. 
On October 31, 1851, Governor James Douglas wrote to the British colonial secretary in London to assure him of the Colony of Vancouver Island's safety. Douglas noted with pride that nothing had occurred to "disturb the tranquility" of the island's settlements since the colony's founding in 1849. ${ }^{2}$ The governor's sanguine assessment, however, masked his concern for the security of the far-flung colony, particularly his growing anxiety about conflict with local Indigenous peoples. ${ }^{3}$ Indeed, Douglas later reasoned that "probably the worst calamity that can befall this colony in its infant state is the hostility of the Native Tribes," and he described Indigenoussettler relations in the Pacific Northwest as "a smouldering volcano, which at any moment may burst into fatal activity." At mid-century, more than 30,000 Indigenous people surrounded a handful of European settlers, mostly clustered around the colony's capital of Victoria. ${ }^{5}$ Given the great population imbalance and the fact that some Indigenous groups had been supplied with firearms, Douglas was worried that increased colonization could - as was the case in other parts of the British Empire at mid-century - spark violent Indigenous resistance and jeopardize the colony's existence. ${ }^{6}$ While the Colonial Office approved the use of British gunboats to patrol the bays and inlets of the Northwest Coast, it refused to dispatch troops to defend the colony against possible attacks from Indigenous inhabitants. ${ }^{7}$ Lacking the funds to support a military force, Douglas deemed it economically and strategically necessary to "cultivate [the] good will" of Indigenous peoples, and so he sought the secretary's advice on how best to manage the population. ${ }^{8}$

One of the means that Douglas considered for cultivating Indigenous peoples' cordiality was education. He informed the colonial secretary, "I am led to regret that the Missionary Societies of Britain, who are sending Teachers to so many other parts of the world have not yet turned their attention to the natives of Vancouvers [ sic] Island." To rectify the situation, Douglas suggested that if religious societies could send out missionary agents, "schools might be established for the moral training and instruction of the Aborigines, to the manifest advantage of the Colony." "Starting in the 1850 s, the British state supported the creation of common schools to train settler children to become better British subjects and to assist with colonization, and so it was thought that missionary schooling could also be used to win over Indigenous peoples to the ways of Europeans to discourage their organized resistance and, in the process, safeguard colonial power. ${ }^{11}$ Based on similar educational experiments among Indigenous peoples in other British colonies, the Colonial Office saw promise in the governor's proposal and approached Christian missionary societies in London about sending out agents to the Pacific Northwest. ${ }^{12}$

This article examines the relationship between settler anxiety, specifically the fears of colonial officials, over conflict with Indigenous peoples - both real and imagined - and the state's early support for missionary schooling in the colonies of Vancouver Island and British Columbia between 1849 and 1871. Historians have highlighted the connection between church and state and colonization in Canada; however, most scholars have suggested that this partnership developed later in the nineteenth century on the west coast. ${ }^{13}$ As such, historians argue that missionaries in what is now known as British Columbia "worked within a framework of governmental 
coercion," but this article demonstrates that, in part to assuage settler anxiety, the nascent colonial state called upon missionaries and assisted their educational efforts to help establish that very framework. ${ }^{14}$ Buttressing colonial security, then, and not benevolence or a deep sense of religious devotion, was the state's main objective in initially aiding missionaries. ${ }^{15}$ Officially, the governments of Vancouver Island and British Columbia refused to provide religious bodies with financial aid to avoid denominational disputes and allegations of favouritism, but unofficially the colonial state invited, directed, and supported early missionary schooling in hopes of cultivating the goodwill of Indigenous inhabitants and strengthening colonial security.

To understand how settler anxiety shaped state support for missionary schooling, this article draws on literature examining the role of emotion and empire. ${ }^{16}$ Scholars such as Ann Laura Stoler argue that colonial records often reflect fears and anxieties, not just about what happened, but also about what was feared could happen. ${ }^{17}$ Drawing on such literature, this article examines the relationship between the expressed anxiety of colonial officials and their decisions to support missionary schooling in the context of three conflicts in the Pacific Northwest: a Lekwungen (Songhees) convergence at Fort Victoria in 1851, the Puget Sound War of 1855-56, and the 1864 Tsilhqot'in (Chilcotin) War. The article argues that anxiety over these conflicts acted as a catalyst, prodding the state to selectively support early missionary schooling as a financially expedient way of trying to contain Indigenous resistance and safeguard colonial security.

\section{First in the Field}

In 1829, Jonathan Green, a representative of the American Board of Commissioners for Foreign Missions, visited several Indigenous communities on the Northwest Coast and called for increased missionary attention to be paid to the area. One of the first to answer the call was Father Honoré Timothy Lempfrit, a Catholic priest who arrived on Vancouver Island in 1849. Lempfrit quickly started teaching Hudson's Bay Company (HBC) servants, the Indigenous wives of fur traders, and interested children from a Lekwungen settlement located directly across from Fort Victoria. The HBC, which Britain had granted a ten-year lease over Vancouver Island, initially provided Lempfrit with a makeshift building to begin his work, and afterwards he erected a house in Victoria that he used as a classroom and chapel to teach upwards of twenty-five pupils.

The HBC gave Lempfrit moral support but no financial aid. He relied on donations from his parishioners. Lempfrit laboured in the colony for two years, and according to Rear Admiral Fairfax Moresby, he was a "very intelligent \& earnest missionary" who was generally "on good terms with the community." ${ }^{18}$ Yet, Lempfrit's relations with the Lekwungen soon soured. In July 1851, only three months before Douglas wrote to the colonial secretary to assure him of the colony's safety, Moresby stated, "the good Padre [became] the cause of anxiety to the settlement, through a misunderstanding with the Indians, when the tribe assembled round the fort in a threatening manner." 19 While little is known about the convergence, it is clear that 
in the eyes of some settlers, Lempfrit's activities among the Lekwungen made him a liability to colonial security.

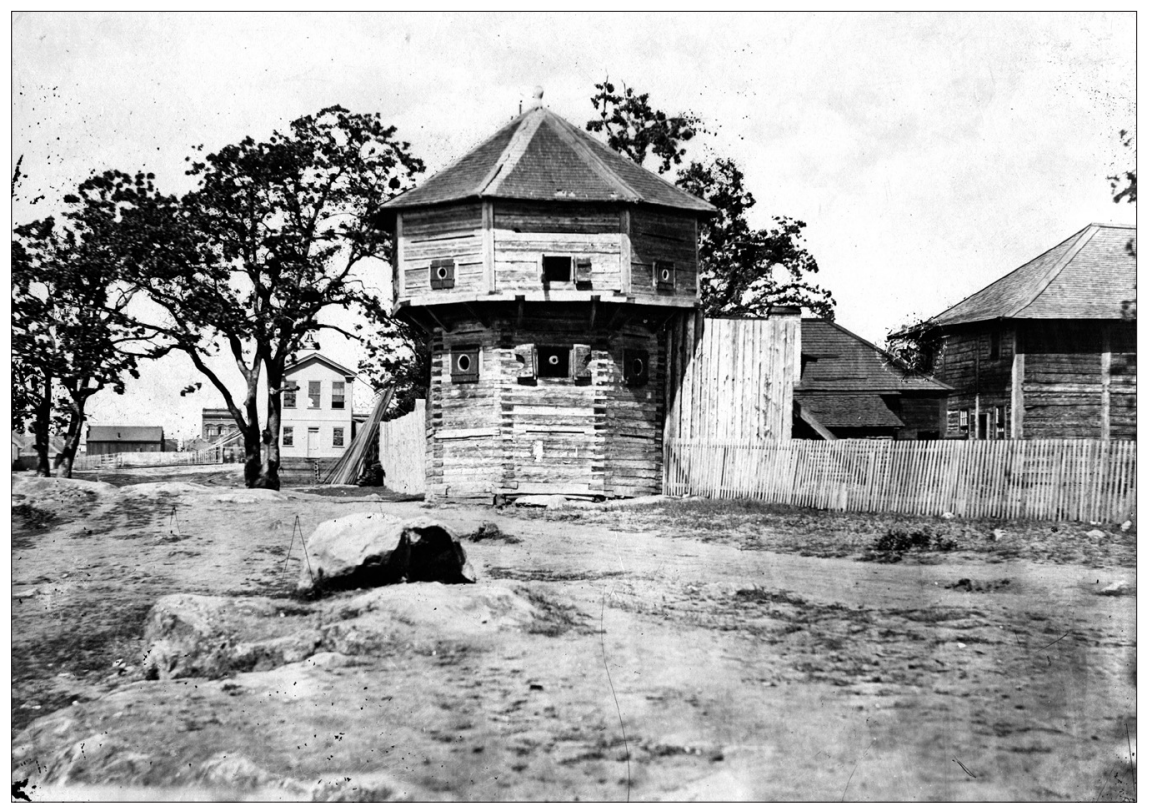

Figure 1: Bastion at Fort Victoria, circa 1850s. Photograph courtesy of Royal BC Museum, A-00903.

In the wake of the incident, Governor Douglas asked Lempfrit to abandon his mission in Victoria. At the request, Lempfrit travelled northwest to live among the Kw'amutsun (Cowichan), who were rumoured to be warlike among the settlers. According to Douglas, this was a tactical error. He explained to the colonial secretary that Lempfrit left Victoria without "a single white assistant, and without any pecuniary means to defray the expense of an establishment, as he trusted entirely to his Indian converts for support; a plan that could hardly be expected to succeed..." ${ }^{20}$ Without colonial assistance, Lempfrit's new mission did not last. In 1852, Douglas wrote to inform the colonial secretary that "we were... lately alarmed by a reported outrage committed by a party of Cowegins" on Lempfrit. In response, the governor "immediately dispatched an officer and a small force, with

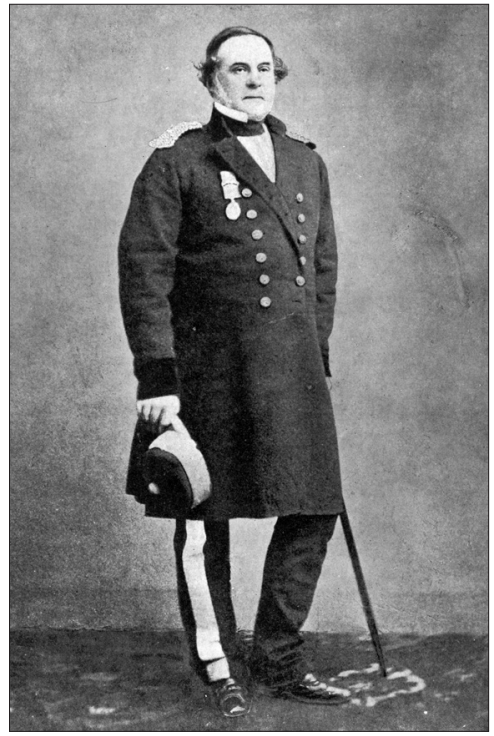

Figure 2: Governor James Douglas. Photograph courtesy of Royal BC Museum, A-01227. 
orders to bring Mr. Lempfrit" back to Victoria. ${ }^{21}$ Lempfrit's labours in the colony were doing more harm than good.

In light of Lempfrit's activities, Douglas initially intended to prevent missionaries from working among Indigenous peoples in the colony. ${ }^{22}$ Given Vancouver Island's small population and limited resources, Douglas thought that "it would be a mere waste of energy" to send missionaries to other parts of the island without any formal support. ${ }^{23}$ Officially, the state did not aid religious bodies so as to avoid denominational disputes and allegations of favouritism. Yet Douglas also believed that encouraging further missionary work among Indigenous peoples would only expose religious agents to danger that would risk sparking "Indian difficulties" and draw the fragile and unprepared colony "into the contest." 24 By discouraging missionaries from overreaching, Douglas felt that he was following "the only safe course, by taking every possible precaution, to prevent the occurrence of difficulties." 25 Many settlers resented Douglas's conciliatory approach to relations with Indigenous peoples, which some disparagingly termed a "squawtocracy." ${ }^{26}$

\section{The Puget Sound War, Settler Anxiety, and the Making of Metlakatla}

Douglas's diplomatic approach, and the prospects for missionary work, began to shift in the fall of 1855, when news reached Victoria of the outbreak of the Puget Sound War, an armed struggle over land rights between Indigenous peoples (Nisqually, Muckleshoot, Puyallup, and Klickitat) and colonizers in Washington Territory. Douglas's feared "Indian difficulties" in the Pacific Northwest had become reality. ${ }^{27}$ James Tilton, the acting governor of Washington Territory, wrote to Douglas explaining that the conflict was a "determined combination among the various Tribes to make war upon us." ${ }^{28} \mathrm{He}$ asked for help in waging war on Indigenous peoples, and Douglas answered the call: "I most cordially acknowledge the moral obligation which binds Christian and Civilized nations to exert their utmost power and influence in checking the inroads of the merciless savage; and it is a cause of sincere regret that our means of sending you assistance comes infinitely short of our wishes." ${ }^{29}$ While lacking supplies, Douglas purchased fifty stand of arms, secured ten barrels of gunpowder, and a supply of ball that he immediately sent on the Traveller. ${ }^{30}$ Extra ammunition was sent on the Beaver. The steamship stayed on to patrol Puget Sound. Douglas hoped that the "moral effect" of the ship's visit "will be powerfully felt by the Native Indian Tribes, and may contribute in some measure to confirm their wavering allegiance and to detach them from the general Indian confederacy." ${ }^{31}$ These actions were in keeping with Douglas's early "Indian policy," which historian Barry Gough argues was "essentially crisis management." 32

Douglas monitored the war to the south closely. He wrote to the colonial secretary and expressed hope that the Indigenous groups would "receive a timely check, or the evil spirit may spread among the aboriginal population of the British Territory." $33 \mathrm{He}$ clarified that in the case of the latter, the colony "would have to bear the brunt of an Indian war, which I trust a kind Providence may avert." ${ }^{34}$ While Douglas explained that Indigenous peoples in the colony remained "quiet and friendly," he remarked 
that nevertheless they were "powerfully moved in favour of their race, a feeling which may exercise a mischievous influence on their excitable minds." ${ }^{5}$ Douglas was anxious. He lamented that the colony could not afford to play an active role in suppressing southern hostilities but hoped that the Indigenous peoples would "soon be made to yield to the palm of victory." 36 By year's end, it appeared that Vancouver Island would be spared from the spread of hostilities.

A few months later, however, Isaac Stevens, the governor of Washington Territory, wrote to Douglas with troubling news. Stevens relayed information about a plan by "Northern Indians" to attack various southern settlements. ${ }^{37}$ Rumours of possible attacks by "hostile" northern groups alarmed settlers. ${ }^{38}$ In March 1856, Douglas received a petition by a "deputation of the most respectable inhabitants of the Colony" asking for a ship to be sent to Victoria. ${ }^{39}$ Anxiety was growing in the colony. The petition read:

May it please your Excellency we the undersigned inhabitants of Vancouvers' [sic] Island beg most respectfully to call your most gracious attention to the Indian war that is now raging on the American shores within a few miles of our own homes. From the most recent accounts the attacks of the Indians have been most frightful and daring atrocities have been committed on the persons of women and children. We are aware that a large number of Indians are on their passage here from the north and it is impossible for any person to calculate to what extent they may be influenced by the accounts. They must undoubtedly hear from the neighbouring Indians. Under these circumstances and from a knowledge that we have no efficient force on the Island and cannot possibly organize such a force for some considerable time if at all, we deem it an imperative duty [... to ask] that one of Her Majesty's ships should be sent here for our protection. ${ }^{40}$

Considering the gravity of the situation, the Colonial Office asked the Admiralty to order the President frigate to report to Vancouver Island. Douglas, too, feared the prospect of northern Indigenous groups joining the fray: "[Recent] events prove how formidable an enemy the Indian may become and react powerfully on the minds of the natives within the British Territory who naturally feel elated at the courage and success of the colored races." ${ }^{41}$ While the dreaded northern delegation failed to materialize, the Puget Sound War generally, and the fear of northern groups joining forces with those in the south to attack colonists, proved to be a catalyst for change in the colony.

Vancouver Island newspapers in the 1850s and 1860s reflected the growing anxiety about potential conflict with Indigenous peoples and urged state officials to take immediate action. The Press stated: "we are all the time living over a mine that may at any instant explode and cause the most serious consequences"; and the Evening Express reported: "we are slumbering unconsciously on the edge of a volcano, which sooner or later will break out into an explosion of bloodshed and flame from one end of the Island to the other." ${ }^{42}$ In the context of continued anxiety, colonial officials devised new means to manage the Indigenous population. Douglas revisited the 
subject of missionary schooling and he informed the Colonial Office that he would now "render every assistance in my power" to assist religious agents. ${ }^{43}$ Douglas saw a role for missionaries to play in using education to neutralize Indigenous peoples' resistance by training them to accept colonization and adapt to European culture, society, and economy.

In contrast to his views of the early 1850s, Douglas now proclaimed that missionaries would find "an extensive field open to missionary enterprise" in British territory, which also included the new mainland colony of British Columbia founded in 1858 as a result of settlers' discovery of gold. ${ }^{44}$ The two most active religious denominations in the area - Anglicans and Catholics — carved out separate spheres of spiritual influence in the region, or what historian Lynn A. Blake calls "denominational geographies." ${ }^{45}$ Anglicans divided mostly into two groups - those sent by the Society for the Propagation of the Gospel in Foreign Parts (SPG) and those by the Church Missionary Society (CMS) — and took over the Northwest Coast and Fraser Canyon. Secular Catholics were active in Vancouver Island and the missionary Oblates of Mary Immaculate dominated the mainland colony of British Columbia, especially the Interior and the lower Fraser valley. Despite their denominational differences, Christian missionaries together started an assault on Indigenous lifeways that was encouraged and assisted directly by the state. While many Indigenous groups resisted and negotiated the arrival of missionaries as active political agents, missionaries nevertheless helped facilitate a gradual shift in the Pacific Northwest's balance of power away from Indigenous peoples in favour of settlers. ${ }^{46}$

In 1856, as the Puget Sound War wound down, the CMS sent out lay missionary William Duncan as the society's first agent to the British Pacific Northwest. Duncan quickly became the most acclaimed missionary in the field. ${ }^{47}$ After working briefly in Victoria, Duncan set sail for the Northwest Coast, arriving at Fort Simpson to work among the Ts'msyan (Tsimshian) on October 1, 1857. He quickly learned to speak Sm'algyax from hereditary chief and HBC employee Arthur Wellington Clah, and his mastery of the local language supported his early efforts at conversion..$^{48}$ To spread his influence, Duncan also established a school at Fort Simpson. In the summer of 1858, a new school was built outside the fort walls and Duncan began teaching there in November 1859. The students were taught a variety of subjects, including reading, writing, and singing, in addition to religious teachings. Mission schools like Duncan's were important institutions of acculturation in colonial British Columbia that gave missionaries daily access to Indigenous peoples to try to transform their traditional ways of life.

Duncan's early success, though, was not restricted to Fort Simpson. Many of his students travelled south to trade in Victoria where they, with their respectable behaviour, caught the attention of the governor. In early 1860, Douglas recruited a trusted advisor and public school official, Rev. Edward Cridge, to write to Duncan about his successful mission. On January 4, 1860, Cridge wrote Duncan to inform him that the governor wished to "express to you the great gratification he has received from conversing with several of the Indians who have been under your instruction at Fort Simpson, and who are now at Victoria, and his please [sic] at witnessing the great 
improvement of manners, learning and religion, which you have succeeded in effecting in their condition." ${ }^{49}$ In the context of fears about northern Indigenous groups joining the Puget Sound War, Douglas was interested in learning about how the lay cleric's "civilizing" methods could be used to prevent future hostilities. Duncan's labours were paying off. In the spring, Douglas even invited the missionary to Victoria to consult him on what might be done to ease settler anxiety and ameliorate the conditions of local Indigenous peoples.

Duncan seized this relationship with the governor to emphasize the good effects of his teachings. While he spoke enthusiastically of the school at Fort Simpson, Duncan desired an independent missionary settlement away from the distractions of fort life and its poor hygienic conditions, which were thought to contribute to the spread of devastating diseases such as smallpox. He wrote Cridge, as the intermediary, to ask the governor for support to establish a separate community. Duncan believed strongly that promising converts, especially the "rising generation," must be "removed from the evil influence" of Fort Simpson; he felt a "growing anxiety for a safe retreat." 50

Douglas thought highly enough of Duncan and his educational work to propose the idea of a missionary settlement to the Colonial Office. The governor wrote to the colonial secretary, the Duke of Newcastle, to ask for imperial sanction to "reserve several hundred acres of land" to "enable Mr. Duncan to carry this useful and benevolent plan with effort." ${ }^{1}$ The Colonial Office approved: "It would be a bright future in British Colonization; and an example to the United States if we can succeed in converting to Christianity and introducing to civilization the native inhabitants, or any portion of them, of British Columbia. To grant a reserve of land as a missionary settlement for converts seems to me a very proper and justifiable proceeding..." 52 Duncan had successfully secured a free grant of land for his educational purposes. ${ }^{53}$

Duncan's plan for establishing a permanent Protestant missionary settlement on the Northwest Coast was approved by the Colonial Office and colonial regime as early as the summer of 1860; however, it would be two years before he attempted a move from Fort Simpson. To relocate his followers, Duncan required financial backing and, once again, he turned to Cridge to broach the subject of pecuniary assistance to Douglas, who was now the governor of both Vancouver Island and British Columbia. In April 1862, Duncan wrote to Cridge regarding the move: "The need of this step is becoming more and more urgent as miners are already rushing up here after gold and I have an idea that many of them will make this place their winter quarters and hence will spring up a serious train of evils." ${ }^{54}$ Separation from Fort Simpson was the key, "I can then take a child or two from each of the surrounding tribes under my care and I have a hope of sending them back to teach in their own people; but this I cannot do at Fort Simpson. Parents have frequently told me that they feel afraid to have their children in this heathen camp, but will have no fear of their being with me under this new arrangement." 55 On the subject of money for his educational efforts, Duncan wrote to Cridge:

When I was last in Victoria I had a long conversation with his Excellency the Governor which turned principally on this subject viz. promoting industry 
among the Indians at their own homes. He assured me that the government would render what assistance they could to promote so considerable [sic] work. Hence I thought of writing to him and begging some government aid... Will you kindly take the favourable opportunity of mentioning the matter to him?" 56

Further progress on the Northwest Coast necessitated financial support from the colonial state. In the wake of the Puget Sound War, and continued settler anxiety about conflict with Indigenous peoples and raids from northern groups, aiding missionary education seemed a reasonable course of action. ${ }^{57}$ Cridge wrote to Duncan on June 21,1862 , informing him that he was to receive a grant of $£ 50$ to aid the creation of his settlement. This transaction is confirmed by a letter from March 6, 1863, in which Duncan thanked the governor for assistance, "The Tsimshean Indians who have [been] lately removed from Fort Simpson under my supervision and settled here are very anxious to tender your Excellency their warmest thanks for the very liberal and timely aid, which you have rendered them, in building their new village." 58 The foundation for a new missionary settlement on the Northwest Coast was laid with state support in the form of a free grant of land and the sum of $£ 50$.

Crucial to Duncan's state-supported missionary experiment was the continuation of his school. He wrote to Douglas after the move to Metlakatla, "We have

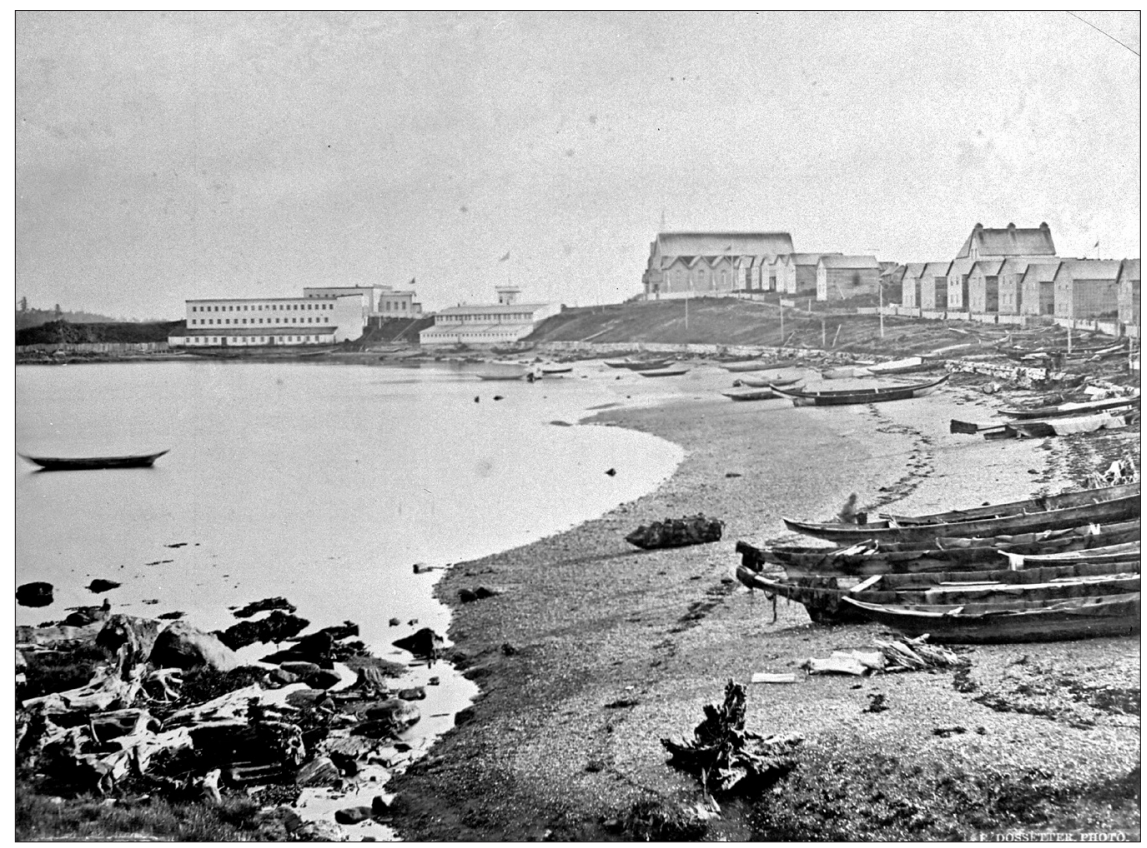

Figure 3: Metlakatla, circa 1860s. William Duncan used St. Paul's Church (centre) as the settlement's first school. Photograph courtesy of Royal BC Museum, B-03571. 
succeeded in erecting a strong and useful building capable of containing at least 600 souls which we use as Church and School." 59 Duncan quickly turned his attention to education. He explained in a letter, "I have about 100 children who attend morning and afternoon and about 100 adults (often more) in the evening. I occupy the principal part of the time with the latter in giving them lectures on the following subjects - Geography, astronomy, natural history, or morals - these lectures they seem greatly to prize." 60 Thus, in the late 1850 s and early 1860 s, the colonial state took an active interest in supporting missionary educational work as a financially expedient way of trying to check Indigenous peoples' power and, in the process, strengthen colonial security.

\section{The Tsilhqot'in War and State Support for St. Mary's}

While Douglas supported Protestant missionaries like Duncan in an effort to "civilize" and contain the threat of feared hostilities with northern groups, the state also supported Catholic missionaries to help stabilize relations between settlers and Indigenous peoples in the southern areas of Vancouver Island and British Columbia. After the unsuccessful work done among Indigenous peoples by Catholic agents like Lempfrit in the early 1850s, Bishop Demers invited the Oblates of Mary Immaculate, the most active missionaries in the field, to Vancouver Island. Overall, Catholics made the most advances in missionary schooling during the colonial period and received substantial encouragement and financial support from the state. This is especially significant considering that many colonial officials, including Douglas, were Protestants.

In the summer of 1858 , conflict between the Nlha7kápmx (Thompson) and invading gold miners broke out in the new colony of British Columbia, and in 1859 Oblate missionaries shifted their activities from Vancouver Island to the mainland colony in hopes of diffusing tensions with their preachings and teachings. ${ }^{61}$ In 1860, Fathers Léon Fouquet and Charles Grandidier, along with Brothers Georges Blanchet and Gaspard Janin, laid the foundation for a mission at New Westminster, British Columbia's capital. From this base, the Oblates travelled inland, going as far as the mining communities of Fort Hope and Fort Yale. Fouquet started exploring options for another mission for Indigenous peoples away from the influences of whites. In 1861, he established St. Mary's Mission near the mouth of the Harrison River, known today as Mission, which was midway

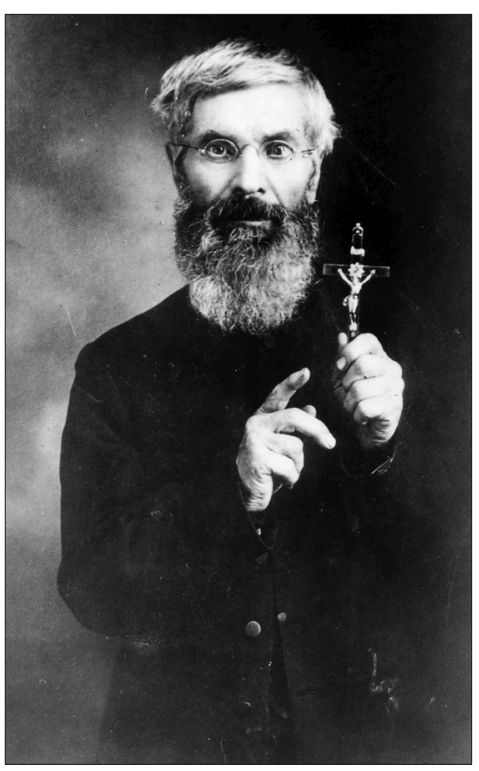

Figure 4: Father Léon Fouquet. Photograph courtesy of Royal BC Museum, I-51542. 
between New Westminster and Fort Hope. The site on the north bank of the Fraser River was selected strategically because it allowed a variety of Indigenous groups from the Interior and the Fraser valley to travel to the mission by water. In 1863 , an industrial school for Indigenous boys was started. Like Duncan's Metlakatla, St. Mary's would become one of the most successful missions in the Pacific Northwest thanks, in part, to support from the colonial state.

The colonial government, though, did not take immediate interest in St. Mary's. Fouquet wrote to Douglas on April 11, 1864, informing him of the Oblates actions and requesting aid to support the institution, specifically for the purposes of education:

That the mission of St. Mary's, to which your memorialist belongs has already an educational and industrial school at the Lower Fraser, where there are at present forty two boys of the aboriginal tribes, supported and provided for by the Mission, and taught the usual branches of common education, viz. Reading, writing, arithmetic... and arrangements have been made for establishing a school for girls...

For consideration of the foregoing mentioned exertions for the amelioration and improvement of the aborigines, your memorialist respectfully requests that some portion of the money appropriated by the Legislature for educational purposes, may be granted to St. Mary's Mission. ${ }^{62}$

Yet, with the school already operating at capacity, and the state's policy of refusing aid to religious bodies, the cash-strapped colony of British Columbia had little incentive to offer aid to St. Mary's. Douglas, who at the time was governor of both Vancouver Island and British Columbia, appears not to have responded to Fouquet's request. As had been the case in the Puget Sound War, however, violent Indigenous resistance to colonization in the spring of 1864 caused a great deal of settler anxiety and proved to be an impetus for change.

When Frederick Seymour took over from Douglas as governor of British Columbia in the spring of 1864 , he was eager to continue to cultivate the goodwill of the Indigenous population. Yet, in late April 1864, just weeks after Fouquet made his request to Douglas for support, Tsilhqot'in warriors waged war on whites in the area of Bute Inlet, killing nineteen men. A wagon road was being built through Tsilhqot'in territory to connect up with the Cariboo Road on the way to Barkerville and the British Columbia goldfields. As road construction continued to Bute Inlet, a group of Tsilhqot'in attacked the construction crew and then moved farther north, killing foreman William Brewster and three others, as well as William Manning, a settler at Puntzi Lake. The Tsilhqot'in generally resented the unauthorized intrusion of whites into their territory, and warriors sought to exact revenge for certain abuses, including the spread of smallpox to the Interior. ${ }^{63}$ When news of the resistance reached Seymour, who had only been governor for a month, he took immediate action to capture the warriors. Under false pretences of amnesty, eight Tsilhqot'in 
men were arrested and five-Klatsassin, Piell, Tellot, Tahpit, and Chessus - were charged with murder. ${ }^{64}$ While Klatsassin protested that the killings were acts of war and not murder, Supreme Court Judge Matthew Baillie Begbie sentenced all five men to death by hanging. The colonial state, fearful of an organized mass uprising, wanted to send a message to all Indigenous peoples that violence against white settlers would not be tolerated. Such actions, though, were not without cost. The entire proceedings drained upwards of approximately $\$ 80,000$ from already cash-strapped colonial coffers.

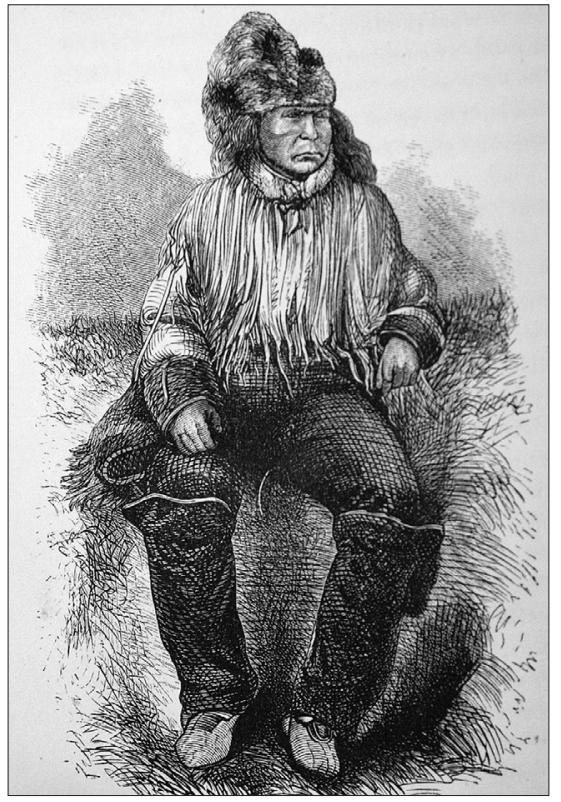

Figure 5: Klatsassin. Sketch from R. C. Lundin Brown, Klatsassin and Other Reminiscences of Missionary Life in British Columbia.

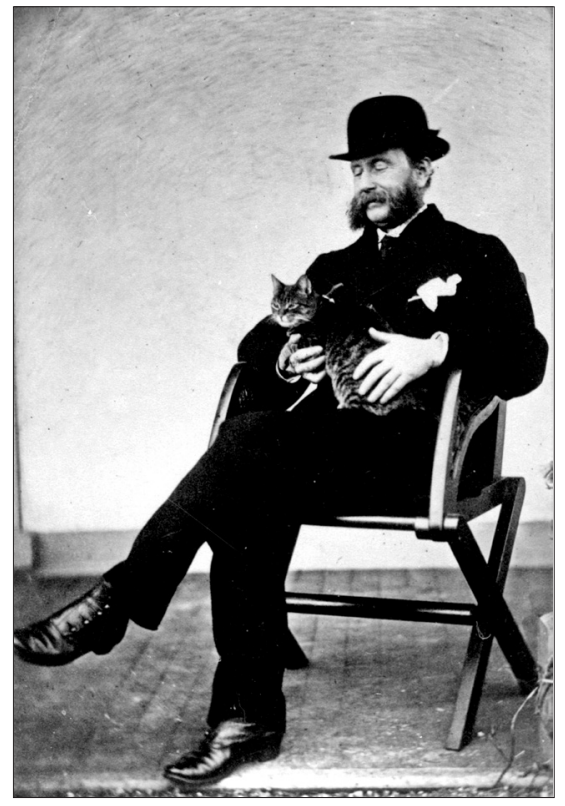

Figure 6: Governor Frederick Seymour. Photograph courtesy of Royal BC Museum, A-01752.

Despite Seymour's swift action, "rumours" of an imminent "general insurrection" of Indigenous peoples circulated throughout British Columbia. ${ }^{65}$ In an attempt to cultivate goodwill and avoid further costly conflicts, Seymour held the first of many successive gatherings of Indigenous groups at New Westminster to celebrate Queen Victoria's birthday in May 1864. At such a turbulent time, Seymour was conscious of the esteem with which many Indigenous peoples had held Douglas, and he wanted to counteract the impression that "their protector was withdrawn and would have no successor." "6r Seymour created the ad hoc summit and invited groups from around the colony to attend as a show of power and to prove that he had "succeeded to all the power of my predecessor and to his solicitude for their welfare." ${ }^{67}$ At the gathering, Seymour announced: 
I am glad to see you and to find that so many have come down to show their loyalty to our Queen. You are right. The Queen has a good heart for the good Indians. I shall be good to them but harsh and severe to the bad ones. I will punish them as they deserve...

I am glad that you wish to be civilized and raised to an equality with the white man. Cultivate your lands, send your children to school, listen to what the clergymen tell you and believe in it. ${ }^{68}$

Seymour saw sagacity in Douglas's strategy of trying to contain Indigenous peoples by cultivating their goodwill, and he identified missionary schooling as an important tool.

In the aftermath of the Tsilhqot'in War, Seymour took a great interest in missionary work, especially the nearby St. Mary's school. In the spring of 1865 , he travelled up the Fraser River to St. Mary's to investigate the facility. Upon his return to New Westminster, the governor wrote to the colonial secretary in London, offering a rare look at the conditions of one of the first industrial schools for Indigenous children in western Canada. ${ }^{69}$ In his report, Seymour commented on the forty-eight pupils in attendance: "Their ages ranged from eight to fourteen years. Their fine healthy appearance and good clothing at once satisfied me, that in this institution at least the native race was not weakening and dwindling by contact with Europeans. Indeed the pupils appeared more robust and active than the boys of their age whom I had seen in the forests and their cheerful faces presented an agreeable contrast to the worn and anxious countenances of the seniors who came to be present at the inspection." ${ }^{\prime 70}$ In terms of the school's amenities, Seymour stated, "The school room was large, clean and well ventilated. It had been decorated with flags, boughs, and ribbons by the boys." ${ }^{11}$ Concerning pedagogy, Seymour observed: "I found them on examination to have made very considerable progress in arithmetic, geography, and spelling. Some of the handwriting was extremely good. The priests have almost entirely thrown aside the inconvenient Chinook medium and teach the boys in English. Even better than the writing was the singing." 72 The pupils at St. Mary's established themselves as excellent musicians, specifically as singers. Seymour remarked, "I have not heard in any school with which I have officially come into contact, here or elsewhere, any piece of music so well delivered as was one Catholic hymn by these Indian boys." ${ }^{\prime 3}$ Overall, Seymour's visit convinced him that "the native race can thrive and improve under civilised habits. Mind and body seemed to have expanded together, and the cultivation of the brain, if one could judge by the demeanor of the students towards their preceptors, to have improved the impulses of the heart." ${ }^{34}$

Seymour was so impressed with the St. Mary's boys that he invited them to the second summit of Indigenous groups at New Westminster in 1865. In recounting the events, Seymour explained: "It rained heavily on the morning of the 24th of May, but a procession was formed of nearly one thousand canoes, extending from one bank of the Fraser to the other. Each boat had its flag and the more civilised of the natives sang a Catholic hymn, which had a very fine effect proceeding from 
thousands of voices upon the water." ${ }^{\prime 5}$ As part of the spectacle, "God Save the Queen was sung by the Indian boys of St. Mary's Mission, and the Indians generally cheered vociferously." 76 Seymour also remarked, "It was generally observed that the Indians had made considerable progress in civilization and wellbeing since I first met them on the 24th May 1864. It was obvious that they were better dressed, and nothing could be greater than the respect with which they treated the constituted authorities of the Colony." ${ }^{7}$ As a result, he suggested, "I allow myself to hope that the native conflicts will soon cease throughout the wide extent of the colony, and the white man will be able to travel anywhere without molestation." "78 Seymour, then, like Douglas, saw "civilizing" efforts such as missionary schooling as playing a role in the strategy of cultivating the goodwill of Indigenous peoples and strengthening colonial security.

Against this backdrop, Fouquet renewed his request for financial support from the colonial government. On August 24, 1865, he wrote to Seymour stating that because of:

the kind interest you have personally showed for the welfare of the Indians, I have the honor to state for the consideration of your Excellency that an average of fifty Indian boys have attended regularly the school at St. Mary's during the last session with results as satisfactory as we could expect. A great many more Indian boys are seeking admission for the next session, but our limited means do not allow us to receive them. Your Excellency is aware that on account of their distant villages and for their better improvement and civilization the Indian boys are kept as boarders... I respectfully request that a portion of the public money... should be granted for the benefit of the children. ${ }^{79}$

On the back of the letter appears the following note: "Authorize a grant of $£ 50$ from the school fund for St. Mary's Mission and School." 80 That the grant was approved is corroborated by a local official, Arthur Birch, who wrote to Fouquet: "I am directed by the Governor to acquaint you that he had been pleased to sanction a grant of $£ 50$ in aid of the St. Mary's school and mission [and I am] instructed to pay you the same on application." 81 Fouquet was thrilled. He explained, "This mark of interest on the part of the government will not only be an encouragement to us to continue to use our utmost endeavours to make the Indians under our care good Christians and good citizens, it will moreover be an inducement as well to the school boys, as to the Indians generally, to improve more and more their condition." ${ }^{2}$

Upon receipt of the government grant for the boys of St. Mary's, Fouquet made a similar request for a school for girls. He wrote to Birch, "we have established a school for girls at New Westminster under the direction of the Sisters of St Ann with two departments, one for white children and the other for half breed and Indian children. Although the average number of pupils in both departments did not exceed twenty two during the first year there are still good prospects of seeing it increased." ${ }^{\prime 3} \mathrm{He}$ suggested that "in consideration of the foregoing your memorialist asks that the government will grant some assistance to the school for the boys at St. Mary's and the school for girls at New Westminster, even if the pecuniary assistance cannot be but 
a small amount." ${ }^{84}$ Later in the month, Fouquet responded to Henry Maynard Ball, magistrate for New Westminster, stating, "I have the honor to acknowledge the receipt of your communication of the 25 th inst. informing me that the sum of $£ 250$ has been appropriated towards the education of the Indian children in our schools of the New Westminster District and to thank the government for it." ${ }^{\prime 5}$ In Fouquet's report for 1865-1866, he confirmed: "The grant we have received from the Government in August 1865 has enabled us to admit ten additional boys from amongst the numerous applicants who were most anxious to become partakers of a good education and thus we increased our number to an average of sixty boarders." 86 Included in Fouquet's report is rare documentation of a student voice in the form of an address made to Birch on a visit to St. Mary's. The address was likely prepared, or at least approved, by a mission authority; however, it remains an important example of students acknowledging the funds the school received from the state: "We are most happy of having another opportunity of thanking you as the representative of Her Majesty as well for your kind visits and for the pecuniary assistance which we have already received and which shall always be remembered by us with feelings of the most sincere gratitude." ${ }^{\prime 7}$

Seymour was pleased with the role that St. Mary's was playing in cultivating the goodwill of Indigenous peoples in the colony. "Civilizing" Indigenous peoples through educational initiatives like St. Mary's was viewed by the early state as supporting the larger strategy of containing Indigenous resistance to colonization and thus, ultimately, helping to strengthen colonial security. Given the financial constraints of the colony after the gold rush, Seymour, like Douglas before him, conceived of granting missionaries small sums of money and tracts of land as a cheaper alternative to outfitting colonial militias to try to quell Indigenous uprisings. By the late 1860 s, the government viewed Catholic missionaries, and Christian missionaries generally, as providing an invaluable service to the colony that warranted state support.

\section{Conclusion}

Indigenous peoples and settlers engaged in innumerable conflicts in the colonies of Vancouver Island and British Columbia between 1849 and 1871. Given the great population imbalance that existed between Indigenous peoples and settlers throughout the period, the threat of violent Indigenous resistance to colonization - both real and imagined - created feelings of anxiety for settlers and colonial officials, and these feelings shaped early state support for missionary schooling. Lacking a military force to effectively counteract organized Indigenous resistance to colonization, the nascent state hoped that missionaries could use education to cultivate the goodwill of Indigenous peoples and strengthen colonial security. Officially, the colonial state refused aid to religious bodies. Unofficially, however, the state supported missionaries in the form of land grants and cash payments and generally encouraged their efforts to create and run mission schools for Indigenous children.

State support for early educational initiatives concerning Indigenous peoples in colonial British Columbia was thus not an act of benevolence, nor one rooted in any great sense of religious duty. The state's objective was for missionaries to act as buffers 
between Indigenous peoples and settlers and to use their teachings to train the former to accept and accommodate themselves to the emerging capitalist settler society. Overall, the state supported early missionary schooling in various ways, as part of a strategy of trying to check the power of Indigenous peoples to strengthen colonial security and bolster British control in the Pacific Northwest.

\section{Notes}

1 I thank Bryan Palmer, Jean Barman, Michael Marker, and the anonymous readers for their helpful comments on earlier drafts of this article. I also gratefully acknowledge the generous funding I received from Trent University's Frost Centre for Canadian Studies and Indigenous Studies, the Social Sciences and Humanities Research Council of Canada's postdoctoral fellowship program, and the University of Alberta's Grant Notley Memorial postdoctoral fellowship program that made this research possible.

2 James Douglas to Earl Grey, October 31, 1851, CO 305/3, 65, National Archives (NA).

3 In 1849, for example, a thirty-six-gun British man-of-war, the Inconstant, was sent to protect Fort Victoria against a gathering of reportedly hostile northern Indigenous peoples. In July 1851, just three months before Douglas wrote to assure the secretary that nothing had occurred to threaten the colony's safety, another gathering of Indigenous peoples took place at Fort Victoria that caused a great deal of anxiety among settlers. See Barry Gough, Gunboat Frontier: British Maritime Authority and Northwest Coast Indians, 1846-1890 (Vancouver: UBC Press, 1984), 25-28. For more on the concept of "settler anxiety" in Vancouver Island during this period, see Kenton Storey, Settler Anxiety at the Outposts of Empire: Colonial Relations, Humanitarian Discourses, and the Imperial Press (Vancouver: UBC Press, 2016). It is important to note that, like Storey's account, this article is focused more on illustrating the connections between the settler psyche and the political economy of colonial education than commenting on the capacity of Indigenous resistance.

4 Douglas to Henry Labouchere, April 10, 1856, CO 305/7, 97, NA; Douglas to Duke of Newcastle, July 28, 1853, CO 305/4, 73, NA.

5 At the time, officials like Douglas did not possess accurate statistics on how many Indigenous people actually existed in the colony and the surrounding territories. Gough argues that settler fears about Indigenous peoples were "intensified because they never knew how many Indians they actually faced. They knew there were thousands, but not how many thousands." Gough, Gunboat Frontier, 9.

6 Storey, Settler Anxiety at the Outposts of Empire, 10. The mid-nineteenth century witnessed a cluster of conflicts across the British Empire: the Matale Rebellion in 1848, the Santhal insurrection of 1855-56, the Indian Revolt of 1857, the New Zealand Wars of 1860-72, and the Morant Bay Rebellion of 1865, to name only a few. For more, see Catherine Hall, Civilising Subjects: Metropole and Colony in the English Imagination, 1830-1867 (Chicago: University of Chicago Press, 2002). Drawing on Indigenous studies literature, I frame incidents of Indigenous "violence" in the context of resistance to colonization. See Ned Blackhawk, Violence over the Land: Indians and Empires in the Early American West (Cambridge, MA: Harvard University Press, 2006); Glen Sean Coulthard, Red Skins, White Masks: Rejecting the Colonial Politics of Recognition (Minneapolis: University of Minnesota Press, 2014).

7 In Gunboat Frontier, Gough argues that Royal Navy gunboats were fitted for service in British Columbia as a "cheap and effective show of power" that could have a "psychological impact" on Indigenous peoples and deter their resistance to colonization 
(13). It is important to note that not all Indigenous peoples responded to colonization in the same way. For more on the diversity of Indigenous responses in British Columbia, see John Lutz, Makúk: A New History of Aboriginal-White Relations (Vancouver: UBC Press, 2008), 49-162. I also acknowledge that the colonial border divided — and continues to divide - Indigenous peoples in the Pacific Northwest. For more, especially in relation to education history, see Michael Marker, "Borders and the Borderless Coast Salish Peoples: Decolonising Historiographies of Indigenous Schooling," History of Education: Journal of the History of Education Society 44, no. 4 (2015): 480-502.

8 Douglas to Newcastle, July 28, 1853, CO 305/4, 73, NA; Douglas to Grey, October 31, 1851, CO 305/3, 66, NA. For more on Douglas, see Adele Perry, Colonial Relations: The Douglas-Connolly Family and the Nineteenth-Century Imperial World (Cambridge: Cambridge University Press, 2015).

9 Douglas to Grey, October 31, 1851, CO 305/3, 66-67, NA.

10 Ibid.

11 For more on common schooling in colonial British Columbia, see Jean Barman, "Transfer, Imposition or Consensus? The Emergence of Educational Structures in Nineteenth-Century British Columbia," in Schools in the West, ed. Nancy M. Sheehan, J. Donald Wilson, and David C. Jones (Calgary: Detselig Enterprises, 1986), 241-264.

12 On schooling in the British Empire, see M. Kazim Bacchus, Education as and for Legitimacy: Developments in West Indian Education between 1846 and 1895 (Waterloo, ON: Wilfrid Laurier University Press, 1994); J. M. Barrington, Separate but Equal? Māori Schools and the Crown, 1867-1969 (Wellington: Victoria University Press, 2008); Catherine Hall, "Making Colonial Subjects: Education in the Age of Empire," History of Education: Journal of the History of Education Society 37, no. 6 (2008): 773-787; Helen May, Baljit Kaur, and Larry Prochner, Empire, Education, and Indigenous Childhoods: Nineteenth-Century Missionary Infant Schools in Three British Colonies (Farnham, UK: Ashgate, 2014).

13 See Robin Fisher, "The Missionaries," Contact and Conflict: Indian-European Relations in British Columbia, 1774-1890 (Vancouver: UBC Press, 1977), 119-145; E. Palmer Patterson II, Mission on the Nass: The Evangelization of the Nishga, 1860-1890 (Waterloo, ON: Eulachon Press, 1982). More nuanced accounts of missionaries in British Columbia continue to downplay the correlation between security concerns and early state support for missionary education in colonial British Columbia. See Lynn A. Blake, "Oblate Missionaries and the 'Indian Land Question,' " BC Studies 119 (Autumn 1998): 28-44; Brett Christophers, Positioning the Missionary: John Booth Good and the Confluence of Culture in Nineteenth-Century British Columbia (Vancouver: UBC Press, 1998); Myra Rutherdale, Women and the White Man's God: Gender and Race in the Canadian Mission Field (Vancouver: UBC Press, 2002).

14 Fisher, Contact and Conflict, 142.

15 On challenging the notion of Canada as a benevolent "peaceable kingdom," see Taiaiake Alfred, Wasáse: Indigenous Pathways of Action and Freedom (Peterborough, ON: Broadview Press, 2005); Paulette Regan, Unsettling the Settler Within: Indian Residential Schools, Truth Telling, and Reconciliation in Canada (Vancouver: UBC Press, 2010).

16 For literature on emotion and empire, see Jane Haggis and Margaret Allen, "Imperial Emotions: Affective Communities of Mission in British Protestant Women's Missionary Publications c1880-1920," Journal of Social History 41, no. 3 (Spring 2008): 691-716; Ann Laura Stoler, Carnal Knowledge and Imperial Power: Race and the Intimate in Colonial Rule (Berkeley: University of California Press, 2002); Stephanie Olsen, Juvenile Nation: Youth, Emotions and the Making of the Modern British Citizen, 1880-1914 (London: Bloomsbury, 2015).

17 Stoler is primarily focused on how colonial anxieties around sexual and racial transgressions shaped the creation of colonial common sense and different governing 
strategies. See Ann Laura Stoler, Along the Archival Grain: Epistemic Anxieties and Colonial Common Sense (Princeton, NJ: University of Princeton Press, 2009).

18 Rear Admiral Fairfax Moresby to secretary of the Admiralty, July 7, 1851, CO 305/3, 228, NA.

19 Ibid.

20 Douglas to Grey, May 28, 1852, CO 305/3, 115, NA.

21 Ibid.

22 This also likely reflected Douglas's perspective as an $\mathrm{HBC}$ official, since the $\mathrm{HBC}$ only reluctantly supported missionaries in their commercial zones. For more, see Gough, Gunboat Frontier, 20-31.

23 Douglas to Grey, May 28, 1852, CO 305/3, 115, NA.

24 Ibid.

25 Ibid.

26 See Gough, Gunboat Frontier, 56. Settler frustrations with Douglas's "forest diplomacy" were no doubt exacerbated by the fact that, like many fur trade officials, Douglas married a Métis daughter of an influential fur trader and that he tried to cultivate a reputation as an Indigenous expert. For more, see Perry, Colonial Relations; Sylvia Van Kirk, "Many Tender Ties": Women in Fur-Trade Society, 1670-1870 (Winnipeg: Watson and Dwyer, 1993), 155-156.

27 On colonial conflict in the Pacific Northwest, see J. A. Eckrom, Remembered Drums: A History of the Puget Sound Indian War (Walla Walla, WA: Pioneer Press Books, 1988).

28 Douglas to James Tilton, November 6, 1855, CO 305/6, 158, NA.

29 Ibid., 160.

30 A "stand of arms" refers to a complete set of weapons for one solider, often meaning a musket, bayonet, cartridge, and box and belt.

31 Ibid., 161.

32 Gough, Gunboat Frontier, xiv.

33 Douglas to Sir William Molesworth, November 8, 1855, CO 305/6, 153, NA.

34 Ibid.

35 Douglas to Tilton, November 19, 1855, CO 305/6, 194, NA.

36 Ibid.

37 Isaac Stevens to Douglas, February 17, 1856, CO 305/7, 33, NA.

38 Indigenous peoples from the north sojourned south for various reasons, most notably to trade in Victoria. Colonists grew worried about the increasing numbers of Indigenous people congregated at Victoria and constantly complained about their perceived immorality, poor hygiene, and lawlessness. Storey argues that "every year between 1854 and 1860, Douglas drew the Colonial Office's attention to the discomfort and anxiety of local settlers regarding the presence of northern First Nations in the community." Storey, Settler Anxiety at the Outposts of Empire, 49-50. For a critical analysis of the racialized and gendered settler discourses about Indigenous peoples during this period, see Jean Barman, "Taming Aboriginal Sexuality: Gender, Race, and Power in British Columbia, 1850-1900,” BC Studies 115/116 (Autumn/Winter 1997/1998): 237-266.

39 Douglas to Grey, March 7, 1856, CO 305/7, 13, NA.

40 Petition included in Douglas to Grey, March 7, 1856, CO 305/7, 17, NA.

41 Douglas to Gret, March 14, 1856, CO 305/7, 5-8, NA.

42 Quoted in Storey, Settler Anxiety at the Outposts of Empire, 56 and 118.

43 Douglas to Sir Edward Lytton, November 6, 1858, CO 60/1, 374, NA.

44 Ibid.

45 Blake, "Oblate Missionaries and the 'Indian Land Question,"” 28.

46 On Indigenous agency and Christianization, see Susan Neylan, The Heavens Are Changing: Nineteenth-Century Protestant Missions and Tsimshian Culture (Montreal and Kingston: McGill-Queen's University Press, 2003). 
47 For more on Duncan's controversial legacy, see Adele Perry, "The Autocracy of Love and the Legitimacy of Empire: Intimacy, Power, and Scandal in Nineteenth-Century Metlakahtla," Gender \& History 16, no. 2 (August 2004): 261-288.

48 For more on Clah, see Robert M. Galois, "Colonial Encounters: The Worlds of Arthur Wellington Clah, 1855-1881," BC Studies 115/116 (Autumn/Winter 1997/1998): 105-148.

49 Edward Cridge to William Duncan, January 4, 1860, CO 60/7, 126, NA.

50 Duncan to Cridge, February 7, 1860, CO 60/7, 133, NA.

51 Douglas to Newcastle, February 18, 1860, CO 60/7, 122, NA. On Douglas's policies concerning Indigenous lands, see Cole Harris, Making Native Space: Colonialism, Resistance, and Reserves in British Columbia (Vancouver: UBC Press, 2002), 17-44.

52 Mr. Elliot on the back of Douglas to Newcastle, February 18, 1860, CO 60/7, 123, NA. In the 1840s and 1850s, Britain was concerned that without proper colonization the United States would try to annex the entire Pacific Northwest. Thus Britain established the Colony of Vancouver Island in 1849 and then, following the discovery of gold on the adjacent mainland, the Colony of British Columbia, in 1858. For more on the history of the Pacific Northwest, see Jean Barman, French Canadians, Furs, and Indigenous Women in the Making of the Pacific Northwest (Vancouver: UBC Press, 2014).

53 It is important to note that the Ts'msyan never formally ceded their lands and, as a result, a struggle for control over Metlakatla broke out in the 1880s between them and the provincial and federal governments. For more on the disputes surrounding the "Indian Land Question," see Paul Tennant, Aboriginal Peoples and Politics: The Indian Land Question in British Columbia, 1849-1989 (Vancouver: UBC Press, 1990).

54 Duncan to Cridge, April 24, 1862, GR-1372, B01322 Box 45, F395, 28, British Columbia Archives (BCA).

55 Ibid.

56 Ibid.

57 The timing of Duncan's request also coincided with the outbreak of smallpox in Victoria and this may have factored into Douglas's support for a relocation strategy. Moreover, it is possible that Douglas thought that Duncan could use education to teach Indigenous peoples about "western" hygiene methods, which could possibly protect against the spread of infection. Indeed, Susan Neylan argues that Duncan gained influence among the Ts'msyan after the move to Metlakatla precisely because he was able to protect the majority of his converts against the spread of the disease. Neylan, The Heavens Are Changing, 211. For more on the devastating effects of smallpox, see Kiran Van Rijn, "'Lo! the Poor Indian': Colonial Responses to the 1862-63 Smallpox Epidemic in British Columbia and Vancouver Island," Canadian Bulletin of Medical History/Bulletin canadien d'histoire de le médecine 23, no. 2 (2006): 541-560.

58 Duncan to Douglas, March 6, 1863, CO 60/15, 368, NA.

59 Ibid., 374.

60 Ibid., 374-375.

61 For more on colonial conflict in the Fraser Canyon, see Daniel P. Marshall, "Claiming the Land: Indians, Goldseekers, and the Rush to British Columbia" (PhD diss., University of British Columbia, 2000).

62 Léon Fouquet to Douglas, April 11, 1864, GR-1372, B01329, Box 59, F 584, 2, BCA.

63 On the Tsilhqot'in War, see Lutz, Makúk, 119-162.

64 In 1865, a sixth Tsilhqot'in warrior, Ahan, was hanged in New Westminster for his part in the attacks. Ibid., 137.

65 Frederick Seymour to Edward Cardwell, August 31, 1864, CO 60/19, 95-97, NA.

66 Ibid., 95.

67 Ibid. On the contested meanings of these summits, see Keith Thor Carlson, "Reservations for the Queen's Birthday Celebrations, 1864-1876," ch. 8 in The Power 
of Place, The Problem of Time: Aboriginal Identity and Historical Consciousness in the Cauldron of Colonialism (Toronto: University of Toronto Press, 2010), 253-279.

68 Ibid., 103.

69 For more on St. Mary's, see Jacqueline Gresko, "Creating Little Dominions within the Dominion: Early Catholic Indian Schools in Saskatchewan and British Columbia," in Indian Education in Canada. Volume 1: The Legacy (Vancouver: UBC Press, 1999), 88-103.

70 Cardwell to Seymour, September 3, 1865, CO 60/12, 548-549, NA.

71 Ibid., 549.

72 Ibid.

73 Ibid.

74 Ibid., 551.

75 Seymour to Cardwell, June 7, 1865, CO 60/22, 74, NA.

76 Ibid.

77 Ibid., $75-76$.

78 Ibid., 76.

79 Fouquet to Seymour, August 24, 1865, GR-1372, B01329, Box 59, F584, 3, BCA.

80 Ibid.

81 Colonial secretary to Fouquet, August 26, 1865, GR-1372, B01329, Box 59, F584, 3 , BCA.

82 Fouquet to Arthur Birch, November 28, 1865, CO 60/22, 462, NA.

83 Fouquet to Birch, July 20, 1866, GR-1372, B01329, Box 59, F584 3, BCA.

84 Ibid., 5.

85 Fouquet to Henry Maynard Ball, July 31, 1866, GR-1372, B01329, Box 59, F584, 6, BCA.

86 Fouquet to the Officer administering the Government, October 25, 1866, CO/25, 184, NA.

87 Copy of address presented to His Honour A. N. Birch by the schoolboys of St. Mary's Mission included in Birch to Earl of Carnarvon, October 25, 1866, CO 60/25, 182183, NA. 